\title{
PENTINGNYA PROMOSI DAN KUALITAS LAYANÄN TERHADAP KELANGSUNGAN HIDUP LEMBAGA PENJUAL JASA
}

Oleh:

Nurhadi

FIS UNY

\section{Abstrak}

Dewasa ini persaingan perusahaan jasa semakin ketat seiring dengan berlangsungkan era globalisasi, dan tidak ketinggalan juga persaingan pada bisnis jasa pendidikan. Sehubungan dengan ini, perguruan tinggi seperti Universitas Negeri Yogyakarta perlu memperhatikan setidaknya aspek promosi dan pelayanannya kepada mahasiswa dan masyarakat luas dalam konteks pemasaran jasanya.

Melalui promosi, Universitas Negeri Yogyakarta dapat momperkenalkan kepada masyarakat luas bahwa jasa layanannya bermanfaat dan dapat memuaskan kebutuhan konsumen. Promosi tersebut bertujuan untuk menarik masyarakat agar tertarik dengan produk yang dif ssilkan lembaga dan akhirnya memutuskan untuk menggunakannya. L ombaga harus dapat memilih strategi promosi yang tepat agar dapat menumbuhkan kesadaran konsumen yang pada akhirnya senantiasa monggunakan jasa yang dihasilkan lembaga, atau menyuruh orang lain untuk menggunakan jasa tersebut.

Kepuasan mahasiswa terhadap pelayanan yang diberikan oleh lombaga muncul setelah mereka menikmati jasa yang ditawarkan. Apabila mahasiswa puas atas layanan yang mereka terima, maka mahasiswa cenderung melakukan pembelian-pembelian jasa berikutnya. Namun bila mahasiswa tidak puas, kemungkinan tidak akan memutuskan untuk menggunakannya lagi, bahkan mungkin akan mengatakan kepada konsumen lain (misalnya siswa-siswa Sekolah Menengah Umum) bahwa Universitas Negeri Yogyakarta tidak memuaskan dan kurang berkualitas.

Kata Kunci: promosi, kualitas layanan

\section{Pendahuluan}

Dalam tulisan ini, lembaga perguruan tinggi yang menjual jasa pendidikan kepada mahasiswanya dianalogikan dengan perusahaan pada umumnya yang menjual jasa pada konsumennya. Di sini pergu- ruan tinggi disejajarkan dengan perusahaan, dan mahasiswa disejajarkan dengan konsumen.

Perubahan selera mahasiswa (konsumen), lingkungan ekonomi dan persaingan yang semakin tajam membuat peran dan manfaat pe- 
masaran menjadi sangat penting bagi perusahaan tersebut dalam rangka mencapai tujuannya. Peran perusahaan saat ini bukan hanya untuk menjual seluruh produk lembaga saja, namun perusahaan harus menyadari bahwa konsumen memiliki berbagai macam kebutuhan yang menuntut mutu dan pelayanan yang tinggi. Banyaknya perusahaan yang menawarkan produk sejenis, mengakibatkan konsumen lebih selektif dalam memilih perusahaan yang memproduksi barang atau jasa yang diinginkannya.

Beberapa ahli telah mencoba merumuskan arti dari pemasaran. Phillip Kotler dalam bukunya yang diterjemahkan oleh Hendra Teguh (1997) mengatakan bahwa pemasaran adalah proses sosial dan manajerial di mana masing-masing individu dan kelompok mendapatkan apa yang mereka butuhkan dan inginkan melalui penciptaan, penawaran dan pertukaran produk yang bernilai bagi pihak lainnya. Kotier menjelaskan bahwa pemasaran merupakan suatu kegiatan usaha yang dipadu untuk mengembangkan rencana-rencana strategis perusahaan yang diarahkan pada pemuasan kebutuhan dan keinginan konsumen. Pemasaran juga digunakan untuk meningkatkan volume penjualan.

Pemasaran bertujuan memberikan kepuasan terhadap keinginan dan kebutuhan konsumen, dan oleh karena itu pemasaran meru- pakan hal yang sangat penting bagi keberhasilan atau kelancaran jalannya perusahaan Agar tujuan dari pemasaran ini dapat tercapai maka kegiatan pemasaran haruslah dimulai dengan usaha mengenal dan merumuskan keinginan dan kebutuhan konsumen. Kemudian perusahaan merumuskan dan menyusun suatu kombinasi dari kebijaksanaan produk, harga, promosi dan distribusi yang tepat agar kebutuhan-kebutuhan konsumen terpenuhi.

Pendek kata, pemasaran bertujuan melayani keinginan konsumen, untuk mendapatkan laba dengan perbandingan yang layak antara revenue dan biaya. Pendekatannya mula-mula menentukan apa yang diinginkan konsumen kemudian melakukan upaya untuk memenuhi keinginan tersebut sehingga konsumen merasa puas.

Kunci untuk mencapai tujuan organisasi adalah menjadikan organisasi tersebut lebih efektif daripada para pesaing dalam memadukan kegiatan pemasaran guna menetapkan dan memuaskan kebutuhan dan keinginan dari pasar sasaran. Sejalan dengan pernyataan ini, Basu Swastha dan Irawan (1997) menyatakan bahwa konsep pemasaran disusun dengan memasukkan tiga elemen pokok yaitu: (a) orientasi pada konsumen atau pasar atau pembeli; (b) volume penjualan yang menguntungkan; dan (c) koordinasi 
danl Inlograsi seluruh kegiatan fernasaran dalam perusahaan.

Jika kita memandang bahwa IIlahatiswa Universitas Negeri Yogvakaila adalah konsumen, maka Ililvolsiltas Nogeri Yogyakarta harus litaa mongidontifikasi kebutuhan maliaslawa yang pada gilirannya berilfaya momonuhinya. Semua pergullanll linggl sobagai perusahaan jasa, leillu monginginkan agar tujuan lembaganya dapat torcapai dan dapat menyestlalkan diri dengan perubahan lingkungan. Lombaga perlu melakikan pengololaan yang baik dalam eselufuli keglatan-kegiatannya, dan ada yang lidak boleh dilupakan yaitu pengelolaan pomasaran. Pengelolaail peinasaran menyangkut program leiencanaan produk, pelaksanaan mogram yang tolah ditetapkan, serta menuevaluasi kogiatan yang telah dilakmanakan. Mongelola dan mengkoordinasl kegiatan pemasaran dengan cara yang baik tersebut dikenal dengan istilah manajemen pemagaran.

Kollor dalam buku yang diterjemahkan oleh Hendra Teguh (1097) menyatakan bahwa manajemon pemasaran adalah proses peiencanaan dan pelaksanaan pemikiran, penentuan harga, promosi seita penyaluran gagasan, baik barang maupun jasa untuk menciplakan pertukaran yang memuaskan lijuan-fujuan individu dan tujuanlijuan organisasi. Manajemen pemaaafan merupakan suatu proses yang menyangkut analisis, perencanaan dan pelaksanaan serta kontrol yang mencakup ide-ide, baik itu barang ataupun jasa yang dilakukan melalui paham pertukaran yang tujuannya adalah untuk menghasilkan kepuasan bagi pihak-pihak lain yang terkait.

Ada dua hal yang berkaitan erat dengan pemasaran jasa lembaga perguruan tinggi yaitu promosi dan kualitas layanan pada mahasiswa. Dua hal tersebut dalam makalah ini akan dibahas secara detail, sebab jika Universitas Negeri Yogyakarta tidak dikenal oleh masyarakat atau jika Universitas Negeri Yogyakarta dikenal oleh masyarakat sebagai lembaga yang peduli terhadap kepentingan mahasiswa sebagai pelanggan maka sedikit demi sedikit masyarakat pelanggan akan menjauhi Universitas Negeri Yogyakarta. Selain dua hal tersebut, pemasaran jasa juga akan dibahas dalam makalah ini.

\section{Promosi}

Manusia mempunyai kecenderungan selalu merasa beluri puas dengan apa yang telah dimilikinya. Manusia, yang selanjutnya kita sebut sebagai konsumen mempunyai kebutuhan yang sangat banyak terhadap barang maupun jasa. Namun mereka cenderung tidak mengetahui perusahaan mana yang dapat menyediakan dan selanjutnya dapat memuaskan dirinya. 
dapat menyediakan dan selanjutnya dapat memuaskan dirinya.

Berawal dari hal tersebut per'sahaan harus mengenalkan produk yang dihasilkannya dengan membentuk tim pemasaran. Tugas pemasar adalah menumbuhkan kesadaran konsumen atau calon pembeli akan keberadaan suatu produk, mulai dari jenis produk sampai dengan cara mendapatkannya. Keberhasilan membangun kesadaran tentang keberadaan suatu produk merupakan langkah awal keberhasilan pihak pemasar dalam suatu perusahaan. Tugas bagian pemasaran yang lain adalah sebagai komunikator di mana pihak pemasar harus dapat merancang bentuk komunikasi yang spesifik dan efektif untuk menumbuhkan rasa ingin memiliki produk yang dipromosikan.

Oleh karena itu, tugas pemasar adalah mengidentifikasi setiap proses yang dilalui calon konsumen dan membangun suatu bentuk komunikasi yang mendorong calon konsumen menuju proses selanjutnya. Pelaku pemasaran harus dapat mencari dan mengembangkan bentuk komunikasi yang ideal sehingga dapat memperoleh perhatian, menarik minat, membangkitkan keinginan dan menghasilkan tindakan.

Promosi merupakan kegiatan yang dilakukan oleh perusahaan untuk menyampaikan atau mengkomunikasikan suatu produk kepada masyarakat. Promosi juga ćigunakan untuk memberikan informasi tentang keberadaan produk, kegunaan dan keistimewaan produk serta untuk merubah sikap ataupun mendorong orang untuk mengkonsumsi.

Nickels, seperti dikutip oleh Basu Swastha (1997) mendefinisikan promosi sebagai arus informasi satu arah yang dibuat untuk mengarahkan seseorang atau organisasi kepada tindakan yang menciptakan pertukaran dalam pemasaran. Sedangkan Rambat Lupiyoadi (2001), menyatakan bahwa promosi merupakan suatu tindakan yang di dalamnya terdapat aktivitas periklanan (advertising), penjualan perorangan (personal selling), promosi penjualan (sales promotion) dan hubungan masyarakat (public relation).

Berdasarkan kedua definisi tersebut dapat disimpulkan bahwa promosi adalah bagian dari marketing mix yang bertujuan meningkatkan penjualan dengan memberikan informasi kepada seseorang atau organisasi. Promosi merupakan salah satu faktor penentu keberhasilan pemasaran, karena konsumen tidak akan pernah melakukan pembelian walaupun suatu produk berkualitas, apabila mereka belum pernah mendengar atau mengetahui apalagi mengenal produk tersebut. Promosi pada hakekatnya adalah suatu bentuk komunikasi pemasaran. Komunikasi yang efektif dapat merubah tingkah laku atau memperkuat tingkah laku yang telah 
lialiwa plosos torsebut terdiri dari bobolapa lahop yaitu tahap kesadatall, lalsap pongetahuan, tahap manvinkal, lialup preferensi, tahap hevalinant solla tahap pembelian.

llonluk bentuk promosi secara iiini111! momiliki fungsi yang sama. Nairilil bordasarkan tugas-tugas hlilatisnya, bentuk-bentuk tersebut dapal dibodakan monjadi personal aellinu, Imass solling, promosi penfualan, public rolation dan direct manholing. lugas-tugas khusus tersebull (lap)al dikombinasikan dan seiling disobut dongan promotional inis

Hentuk mass selling dan dublie relation conderung digunakan olel, porusaluan yang melayani hepentingan umum. Mass selling IIerupakan pondekatan yang menggimakan modia komunikasi untuk imenyampaikan informasi kepada hhalayak dalam satu waktu. Mass aelling dapat berbentuk periklanan maupun publikasi. Sedangkan public celalion merupakan bentuk komunihasl secara menyeluruh dari suatu perusahaan untuk mengetahui dan mompengaruhi persepsi, opini, keyakinan dan sikap berbagai kelompok terhadap perusahaan.

Adanya berbagai bentuk promosl torsebut, perusahaan harus pandal-pandai memilih metode mana yang paling sesuai. Faktor-faktor vang harus dipertimbangkan oleh perusahaan dalam setiap pemilihan metode promosi adalah sebagai berikut :

a) Faktor Produk, berupa karakteristik produk, cara produk itu di beli dan.siklus kehidupan produk tersebut.

b) Faktor Pasar, misalnya permintaan konsumen, persaingan dengan perusahaan sejenis dan lain-lain.

c) Faktor pelanggan, misalnya selera konsumen, tingkat pendidikan, tingkat pendapatan dan usia konsumen.

Adapun media yang dapat digunakan dalam promosi antara lain: (1) media cetak yang dapat berupa surat kabar, majalah, brosur dan tabloid; (2) media elektronik yang dapat berupa televisi, radio serta internet; (3) media luar ruang yang meliputi papan nama, spanduk dan lain-lain; dan (4) media lini bawah yang terdiri dari pameran, penerangan dan kalender.

\section{Kualitas Layanan}

Fandy Tjiptono (2000), menyatakan bahwa kualitas layanan merupakan suatu kondisi dinamis yang berhubungan dengan produk, jasa, manusia, proses dan lingkungan yang memenuhi atau melebihi harapan. Definisi kualitas layanan ini mengandung makna bahwa kualitas layanan (1) merupakan usaha memenuhi atau melebihi harapan pelanggan; (2) mencakup produk, jasa, manusia, proses dan 
usaha memenuhi atau melebihi harapan pelanggan; (2) mencakup produk, jasa, manusia, proses dan lingkungan; (3) merupakan su-.u kondisi yang terus berubah. Oleh karena itu, kualitas pelayanan merupakan suatu bentuk kesesuaian antara pelayanan yang diharapkan oleh konsumen dengan pelayanan yang ditawarkan oleh perusahaan.

Dewasa ini kegiatan pemasaran tidak terlepas dari kualitas layanan terhadap konsumen. Kualitas layanan yang baik dan tepat akan mempengaruhi konsumen dalam membuat keputusan untuk pembelian suatu produk. Fandy Tjiptono (2000) menyatakan bahwa pada prinsipnya ada tiga kunci pokok dalam memberikan pelayanan yang unggul yaitu : (a) kemampuan memahami kebutuhan dan keinginan konsumen; (b) pengembangan data base yang lebih akurat daripada perusahaan pesaing; dan (c) pemanfaatan informasi-informasi yang diperoleh dengan riset pasar dalam suatu kerangka strategi yang diwujudkan dalam pengembangan relationship marketting.

$\mathrm{Di}$ atas telah disebutkan bahwa kunci kesuksesan perusahaan jasa terletak pada kemampuannya untuk menyesuaikan atau bahkan melebihi harapan pelanggan dalam hal kualitas. Harapan pelanggan merupakan hasil dari pengalaman mereka, kata-kata orang serta iklan perusahaan jasa. Konsumen memilih penyedia jasa atas dasar ini dan setelah menerima jasa mereka membandingkan kualitas yang dirasakan dengan kualitas yang mereka harapkan. Jika kualitas pelayanan yang diberikan sesuai dengan yang diharapkan, konsumen cenderung untuk menggunakannya lagi jasa layanan perusahaan tersebut. Namun apabila kualitas layanan yang dirasakan konsumen berada di bawah kualitas yang diharapkan, konsumen akan merasa kecewa dan cenderung meninggalkan penyedia jasa tersebut.

Dimensi kualitas layanan yang digunakan untuk mengevaluasi kualitas pelayanan menurut Fandy Tjiptono (2000) adalah:

a. Bukti langsung (tangibles), meliputi fasilitas fisik, perlengkapan, pegawai dan sarana komunikasi.

b. Keandalan (reliability), kemampuan memberikan pelayanan yang dijanjikan dengan segera, akurat dan memuaskan.

c. Jaminan (assurance), mencakup pengetahuan, kemampuan, kesopanan dan sifat dapat dipercaya yang dimiliki para staf, bebas dari bahaya, resiko atau keraguraguan.

d. Daya tanggap (responsiveness), keinginan para staf untuk membantu pelanggan dan memberikan pelayanan dengan tanggap, cepat dan memuaskan.

e. Empati, yang meliputi kemudahan dalam melakukan hubungan, ko- 
Konsep pemasaran terkait dengan strategi pemasaran. Strategi fiematiaran tersebut menurut Imam Nullinawan (1997) terdiri dari prinsipliitisilp dasar yang mendasari manafeillen pemasaran untuk mencapai IIIIuan bisnis dan pemasarannya dalaili soluth pasar sasaran. Strategi fiemasaran tersebut mengandung hepultusan dasar tentang pengellatall pemasaran, bauran pemasarall dan alokasi pemasaran.

6tralogi sobagai alat yang akanl digumakan untuk mencapai lijuall perusahiaan, merupakan rencana jangka panjang yang digunakan sebagai pedoman bagi kegiatankegiatan perusahaan. Penentuan stralegl pemasaran perusahaan dilakukan olelı manajer pemasaran dengan membuat tiga macam kepulusan yaitu tontang pengeluaran yang lerkail dengan pemasaran, bauran pemasaran, dan alokasi

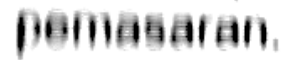

\section{Pemagaran Jasa}

Jasa, sebagaimana dikemukakan Kotler yang diterjemahkan oleh llendra Toguh (1997) yaitu setiap lindakan atau kegiatan yang dapat ditawarkan suatu pihak kepada pihak lain yang pada dasarnya tidak dapat diliiliat dan tidak dapat menghasilkan liak millik torhadap sesuatu. Produksinya dapat berkenaan dengan sebuah produk fisik ataupun tidak. Sealan dengan pendapat tersebut, Fandy Tilptono (2000) menyatakan bahwa jasa merupakan aktivitas, manfaat atau kepuasan yang ditawarkan untuk dijual yang pada dasanya tidak menghasilkan hak milik terhadap sesuatu. Sesuai dengan konsep jasa tersebut, maka jasa memiliki empat karakteristik yang sangat mempengaruhi rancangan program pemasarannya. Keempat karakteristik tersebut menurut Fandy Tjiptono (2000) meliputi :

\section{(a) Intangibility}

Jasa bersifat intangible, artinya tidak dapat dilihat, dirasa, diraba, dicium atau didengar sebelum dibeli. Dalam hal ini perusahaan jasa menghadapi tantangan-tantangan untuk memberikan bukti-bukti fisik dan perbandingan pada penawaran abstraknya.

(b) Inseparable Jasa biasanya dijual terlebih dahulu, baru kemudian diproduksi dan dikorisumsi secara bersamaan. Interkasi antara penyedia jasa dan pelanggan merupakan ciri khusus dalam pemasaran jasa.

(c) Variability

Jasa pada dasarnya bersifat sangat variabel karena merupakan non standardized output, artinya banyak variasi bentuk, kualitas dan jenis tergantung pada siapa, kapan dan di mana jasa tersebut dihasilkan.

(d) Perishability 
dan jenis tergantung pada siapa, kapan dan di mana jasa tersebut dihasilkan.

(d) Perishability

Jasa merupakan komoditas tidak tahan lama dan tidak dapat disimpan. Bila jasa tidak digunakan maka jasa tersebut akan berlalu begitu saja.

Mengingat karakteristik jasa yang cukup unik tersebut, maka bisnis jasa memerlukan perhatian yang lebih mendalam dalam pengelolaannya. Kesulitan konsumen untuk mengetahui hasil dari produk yang ditawarkan perusahaan dapat diatasi dëngan mempertunjukkan kualitas produk melalui bukti fisik (physical evidence). Konsumen akan menyimpulkan kualitas jasa dari tempat, peralatan, karyawan dalam perusahaan jasa, simbol perusahaan dan harga yang mereka amati. Faktor lain yang tidak kalah penting adalah pemberian perhatian khusus pada tingkat partisipasi atau keterlibatan pelanggan dalam proses jasa. Interaksi antara penyedia jasa dan pelanggan merupakan ciri khusus dalam pemasaran jasa. Keduanya mempengaruhi tingkat keberhasilan pemasaran.

Keputusan konsumen merupakan sikap seseorang untuk membeli atau menggunakan suatu produk baik berupa barang maupun jasa yang telah diyakini akan memuaskan dirinya dan kesediaan menanggung resiko yang mungkin ditimbulkannya.
Konsumen mengambil banyak keputusan pembelian setiap hari. Pemasar perlu mengetahui apa saja yang menjadi bahan pertimbangan konsumen dalam keputusan pembelian.

Keputusan konsumen untuk membeli atau menggunakan suatu produk meliputi :

1. Keputusan tentang jenis Produk

2. Keputusan tentang bentuk Produk

3. Keputusan tentang penjualnya

4. Keputusan tentang waktu pembelian

5. Keputusan tentang cara pembayaran

Ada beberapa tahapan yang dilalui konsumen untuk mencapai suatu keputusan pembelian. Tahapan-tahapan yang dilalui konsumen dalam pengambilan keputusan pembelian meliputi pengenalan produk, pencarian informasi, evaluasi alternatif, keputusan pembelian dan perlaku purna beli. Tahapan-tahapan tersebut menekankan bahwa proses pembelian berawal jauh sebelum pembelian sesungguhnya juga berakibat jauh sesudahnya.

Dengan merespon tahapantahapan pembelian tersebut mendorong pihak pemasar untuk lebih memusatkan perhatian pada proses pembelian, bukan hanya mencurahkan perhatiannya pada keputusan pembelian. Proses pembeliar yang dimulai dengan pengenalar produk dilanjutkan dengan konsu. men merasakan adanya kebutuhar 
foillı mononlukan faktor-faktor dan Glliabal yang biasanya menimbulkan inimal komsumon dan menyusun fingyianl pemasaran tentang produk iiil

Ialiapan borikutnya adalah fenteatian liformasl. Soorang konsuHien valig lardorong oloh kebutuhannya minnukin akan molakukan penEallan Infomas lobil lanjut. Misalliva aaja konsumon mulai memperlialikan thlan produk yang dibutuhhannya alau momporhatikan produk yang sama yang digunakan orang lain Konsmmen tersobut dapat memperoleh informasi dari banyak sumber fletubungan dengan hal ini pemasar harus menguasai tentang aumber sumbor yang paling diminati aerla menarik bagi calon pembeli.

timnor-sumber informasi baal honguminen torsobut menurut Imam Nufmawan (1097) antara lain:

1) Éumber mibadi, meliputi keluar0a, teman, tolangga kenalan.

9) Eumber komersiil, terdiri dari iklan, wiraniaga, penyalur, pengemasan

3) Sumber publik, antara lain media massa, organisasi konsumen

A) tumber oksperimensial, meliputi penanganan, pengujian, dan penggunaan.

Dalam tahap keputusan pembelian atau penggunaan, ada dua laktor yang akan muncul untuk mempengaruhi niat pembelian menuju kepulusan pembelian. Faktor tersebut adalah sikap orang lain dan situ- asi yang tidak diinginkan. Pengambilan keputusan pembelian suatu barang atau jasa akan melibatkan berbagai pihak, sesuai dengan peran masing-masing. Peran yang dilakukan tersebut menurut Basu Swastha dan Hani Handoko (1997) adalah :

1) Initiator, yaitu individu yang mempunyai inisiatif pembelian barang atau jasa tertentu.

2) Influencer, yaitu individu yang berpengaruh terhadap keputusan pembelian.

3) Decider, yaitu yang memutuskan akan membeli atau tidak, apa yang akan dibeli, bagaimana membelinya, kapan dan di mana membelinya.

4) Buyer, yaitu individu yang melakukan transaksi pemebelian sesungguhnya.

5) User, yaitu individu yang mempergunakan produk barang atau jasa yang akan dibeli.

Orang yang akan melakukan transaksi pembelian dan orang yang menggunakan produk baik barang maupun jasa mempunyai peran penting terutama berkaitan dengan kepuasan dan kesediaan membeli ulang, namun dari kelima peran tersebut pengambil keputusan merupakan peran yang terpenting. Perusahaan dapat meneliti siapa yang berperan dalam pengambilan keputusan tersebut, untuk selanjutnya dapat mengarahkannya menggunakan produk yang kita tawarkan. 
yang berperan dalam pengambilan keputusan tersebut, untuk selanjutnya dapat mengarahkannya menggunakan produk yang kita tawarkan.

Tahap terakhir dalam proses pengambilan keputusan adalah perilaku purna beli. Tugas pemasar tidak berakhir pada saat produk sudah dibeli tetapi berlanjut sampai pada periode sesudah pembelian. Konsumen akan merasa puas atau tidak puas dengan produk yang sudah dibeli. Apabila ia puas, ia akan cenderung membeli lagi dan bahkan mungkin akan mengajak orang lain untuk ikut menikmatinya. Sedangkan jika pembeli merasa kecewa dengan apa yang telah dibeli, maka pembeli tidak akan membelinya lagi dan cenderung mengingatkan orang lain untuk tidak membeli produk tersebut. Pembeli yang merasa kecewa dengan produk yang telah dibeli dapat merusak sikap konsumen lain atau calon konsumen terhadap suatu perusahaan berikut barang atau jasanya.

Berawal dari hal tersebut, perusahaan hendaknya secara teratur mengukur tingkat kepuasan pelanggan, agar dapat segera diketahui apabila ada hal yang kurang dalam produk yang dihasilkan perusahaan. Dalam hal ini fungsi controling output perlu sekali dijalankan sehingga keberlanjutan hidup perusahaan lebih terjamin.
Universitas Negeri Yogyakarta sebagai lembaga penjual jasa pendidikan hendaknya juga selalu mengukur tingkat kepuasan mahasiswanya dengan maksud agar dapat segera diketahui apabila terdapat pelayanan yang kurang menyenangkan. Dengan mengetahui tingkat kepuasan mahasiswa tersebut, maka Universitas Negeri Yogyakarta bisa segera merumuskan kebijakan-kebijakan strategis guna lebih memuaskan mahasiswanya.

\section{Penutup}

Sebagai penutup, di sini dapat dikemukakan beberapa kesimpulan yang disarikan uraian di atas yaitu:

1. Promosi merupakan kegiatan yang dilakukan oleh perusahaan untuk menyampaikan suatu barang atau jasa kepada masyarakat. Melalui promosi, lembaga dapat memperkenalkan kepada konsumen bahwa produknya bermanfaat dan dapat memuaskan kebutuhan konsumen. Promosi bertujuan untuk menarik konsumen agar tertarik dengan produk yang dihasilkan lembaga dan akhirnya memutuskan untuk menggunakannya.

2. Promosi juga bertujuan untuk mengingatkan pemakai jasa akan kelangsungan hidup dari jasa yang dipromosikan. Apabila konsumen puas karena menggunakan barang atau jasa yang dihasilkan oleh suatu lembaga tersebut maka konsumen diha- 
hasadaran konsumen yang pada aklilinya monggunakan jasa yang diliasilkan lombaga, atau menyuIili orang lain untuk menggunahair Jasa torsobut.

I Kepmatan mahasiswa terhadap pelayanan yang diberikan oleh lembaga muncul sotolah mereka menllkmall jasa yang ditawarkan. Apabila mahasiswa puas setelah mengumakan jasa lombaga, maha mereka cenderung melakukan nembelian pembelian jasa berihulnya. Namun bila mereka tidak 0uas, kemungkinan tidak akan memutuskan untuk menggunahannya lagi, bahkan mungkin akan mengatakan kepada konsumen lain (misalnya siswa-siswa Eekolalı Menengah Umum) bahwa lembaga yang menawarkan jasa lorsebut tidak memuaskan dan kurang berkualitas.

\section{Daflar Pustaka}

Basu Ewastha, (1997), Asas-asas Markoling, Yogyakarta: Liberty.

Basu Ewastha dan Irawan (1997), Manajomen Pemasaran Modern, Yogyakarta: Liberty.

Fandy Tjiptono, (1997), PrinsipPrinsip Total Quality Service, Yogyakarta: Andi Offset. (2000), Manajemen Jasa, Yogyakarta: Andi Offset.
Imam Nurmawan, (1997), PrinsipPrinsip Pemasaran, Yogyakarta: LPFE-UII.

Indriyo Gitosudarmo, (1995), Manajemen Pemasaran, Yogyakarta: BPFE.

Kottler, Phillip, (1997), PrinsipPrinsip Pemasaran (Terjemahan Imam Nurmawan), Yogyakarta: LPFE-UII. (1997), Manajemen Pemasaran (Teijemahan Hendra Teguh), Surakarta: Pa-belan.

Rambat Lupiyoadi, (2001), Manajemen Pemasaran Jasa; Teori dan Praktik, Jakarta: Salemba Empat.

\section{Biodata}

Drs. Nurhadi, MM adalah dosen Manajemen FIS Universitas Negeri Yogyakarta 